\title{
Representations of tropical forests and tropical forest-dwellers in travel accounts of National Geographic
}

\section{Nygren, Anja}

White Horse Press

2012

Nygren , A 2012 , Representations of tropical forests and tropical forest-dwellers in travel accounts of National Geographic . in S Johnson (ed.), Indigenous knowledge. Themes in environmental history, vol. 3 , White Horse Press, Cambridge, pp. 1-20 .

http://hdl.handle.net/10138/231420

acceptedVersion

Downloaded from Helda, University of Helsinki institutional repository.

This is an electronic reprint of the original article.

This reprint may differ from the original in pagination and typographic detail.

Please cite the original version. 


\title{
REPRESENTATIONS OF TROPICAL FORESTS AND TROPICAL FOREST-DWELLERS IN TRAVEL ACCOUNTS OF NATIONAL GEOGRAPHIC
}

\author{
Anja Nygren \\ University of Helsinki \\ Finland \\ Email: anja.nygren@helsinki.fi
}

\section{ACKNOWLEDGEMENTS:}

This essay draws on research financed by the Academy of Finland and the University of Helsinki. Stephen Nugent provided valuable comments on a previous version of this essay. Of course, I remain solely responsible for any errors of facts or interpretation. 


\begin{abstract}
As one of the most widely read genres of literature, travel writing has a crucial role in formulating the popular images and understandings of foreign places and foreign peoples. This essay examines the dominant images of rainforests and rainforest peoples portrayed in the travel accounts by National Geographic on tropical America. Special attention is paid to the issues of how particular representations are privileged in the magazine's travel accounts and how these representations relate to questions of authority and power. The analysis shows that the prevailing representations of the tropical forests and tropical forest-dwellers in the travel accounts of National Geographic rely on historically changing, but equally categorical distinctions between the 'good' and the 'evil', and the 'natural' and the 'unnatural'.
\end{abstract}

Keywords: travel writings, representations, images, tropical forests, tropical forest peoples

\title{
INTRODUCTION
}

Far-off and fabulously exotic tropical lands and tropical peoples have long inspired curiosity and aroused the imagination finding expression in both scholarly and journalistic writing (Raffles 2002, Slater 2002, Stepan 2001). Travel writing is one of the most important sources of popular discourses and images of tropical landscapes and tropical peoples. As such, travel writers play a crucial role in shaping the public understandings concerning tropical forests and tropical forest-dwellers, as well as in regulating the public opinions in relation to policy implications important to be implemented in the tropics (Arnold 1996: 141-68, Duncan and Gregory 1999, Holland and Huggan 1998: 67-81).

In this essay, I examine the highly selective, essentialist images that have come to represent indigenous and non-indigenous forest-dwellers in travel accounts of National Geographic on tropical America. This famous U.S. magazine, with an authoritative voice and a total circulation of 9,5 million copies per month offers an excellent source to analyze the discourses and images that have come to 
represent neotropics and its peoples in Western popular imagination. ${ }^{1}$ My main aim is to show how particular representations and discourses are privileged in the magazine's travel accounts and how they operate in order to create hierarchical polarities. For the purpose of this examination, I have analyzed all the relevant travel writings with a focus on neotropics and neotropical forest-dwellers that were published in National Geographic (earlier The National Geographic Magazine) during the years 1888-2004. Most of these, in total, forty accounts were written by British or U.S. travellers.

Anthropologists, geographers, and literary historians have recently called attention to a rich corpus of 'Western' narratives, that tend to categorize 'non-Western' peoples as racial, cultural, and gendered others. ${ }^{2}$ Torgovnick (1990), Arnold (1996) and Stepan (2001) analyze the discourses of primitivism and otherness embedded in Western thinking about the tropics, while Pratt $(1992,1994)$ examines the imperialist discourses interwoven in the early Western travel writings on the world outside Europe. Lutz and Collins (1993) analyze the images of non-Western peoples as exotic others as portrayed in National Geographic, while Rothenberg (1994) examines the magazine's representations of nonEuropean women as mysterious and naturally erotic others. Ramos $(1994,1998)$ and Slater (1996, 2002) offer inspiring analyses of the historical trajectories of the images of the Amazonian rainforests and the Amazonian Indians as now infernal, now paradisal others.

Characteristic of many of these analyses is the view that Western narratives of the non-Western world rely on a powerful distinction between 'us' and 'them' (Lutz and Collins 1993: 26, 110-11, Torgovnick 1990). My research on travel accounts by National Geographic starts from a somewhat different point of view. As will be shown in the following analysis, the poles of this dichotomy are not simply 'we' and 'the other', or 'the West' and 'the rest'. Instead, the accounts produced by National Geographic construct essentialist images of tropical forest-dwellers as either 'excellent' or 'evil' others. Whereas most of the late nineteenth century and early twentieth century travel writings of National Geographic presented rainforest Indians as violent savages and the non-indigenous farmers as progressive pioneers, this distinction began to reverse in the early 1970s. In accordance with the growing global concern of tropical deforestation and increasing attention to tropical rainforests as 
remarkable sites of biodiversity protection, recent travel accounts tend to produce images of rainforest Indians as 'noble natives', dwelling in nature according to nature, while small-scale settlers and nonindigenous rural poor are portrayed as 'ignoble villains', in need of control and order. ${ }^{3}$

This duality in the Western views of the other, as either good and peaceful, or bad and violent, is implicitly proposed by Torgovnick (1990: 3) in her statement that primitive peoples 'exist for us in a cherished series of dichotomies; by turns gentle, in tune with nature, paradisal, ideal - or violent, in need of control; what we should emulate or, alternatively, what we should fear'. This challenging idea, also suggested by Slater (2000: 78), has, however, rarely been elaborated further in representational analyses of tropical forest-dwellers. Especially when dealing with representations of Amazonia, the attention has so strongly focused on the 'majestic forests' and 'mysterious Indians' that the non-indigenous residents have largely remained invisible. As remarked by Nugent (1993: 21), the non-indigenous Amazonians represent a discrepant other, considered to be blessed with little culture and little history and thus lacking sufficient status of difference to be included in discussions of Amazonia.

Based on the theoretical argumentations by Lutz and Collins (1993: 1-3), the focus in the following analysis will not be so much on how 'realistic' the images presented in the travel writings of National Geographic of tropical forest-dwellers are, but on the imaginative spaces that the tropical peoples occupy in the travel writers' minds. Narratives about foreign places and alien practices, whether scientific or not, are never simple documents nor objective mirrors of reality. They also reinforce or challenge general understandings of cultural similarity and difference, thus reflecting much on who is behind the text (Briggs 1996, Graham 2002, Oakdale 2004). As will be demonstrated below, the predominance of particular representations at a particular time depends not so much upon essential differences between the target populations themselves, but upon the prevailing regimes of representation and procedures of social and political influence that shape the travel writers' ways of seeing and ways of interpreting the issues under consideration (Duncan and Gregory 1999, Porter 1993, Schwartz 1996). 
In this connection, the images presented in the travel narratives of the tropics and tropical peoples can not be simply dismissed as incorrect or false. Instead, they need to be examined in relation to the contexts in which they are generated and the purposes they serve. Certain representations become socially dominant not merely on rhetorical grounds; they are also closely related to the issues of authority and power (Conklin 2002, Jackson 1997, Li 2000). In producing feelings of closeness and empathy with some, and distance and discredit towards others, narratives of tropical forests and tropical forest-dwellers build upon social classifications and moral cartographies that construct hierarchical patterns of otherness. At the same time, these narratives have considerable influence on popular understandings concerning the environmental agendas and environmental policies to be implemented in the tropics.

My examination of the travel accounts under study combines qualitative content analysis with textual interpretation in an effort to identify the characteristic representations they construct, and the transformations and consistencies in these representations over time. For analysis, I have utilized the QSR N6 qualitative data analysis programme. ${ }^{4}$ Owing to space limitations, I will focus here on what I take to be the dominant representations in the analyzed accounts. This does not, however, imply that the perceptions of neotropical forests and neotropical peoples portrayed in these accounts were absolutely reified or monolithic. As remarked by Arnold (1996: 142-57) and McEwan (1996), the images of tropical forests and tropical peoples, although essentialist and stereotypical, can also be ambivalent, containing elements of different sets of imagery side by side. ${ }^{5}$ In this respect, it is important to note that the selection of the images and representations accepted for publication in such a well-established brand as National Geographic, is often a result of negotiation and compromise among various stakeholders and their personal and institutional ambitions. The following analysis aims to understand the radical alteration in the images of indigenous and non-indigenous forestdwellers in the accounts by National Geographic during the 1970s within the changing context of travelling and changing role of tropical rainforests in the global environmental discourses and policies. 


\section{CONQUERRING THE 'GREEN HELL'}

Characteristic of late-nineteenth century and early-twentieth century travel writings of National Geographic on tropical America is the view of tropical forests as an impediment and/or a challenge. Rainforests are considered to be demeaning peripheries as well as landscapes of abundant potentiality. These views have much to do with the social and political climate of scientific and economic exploration in which many of these travellers entered the neotropics. Many of them were 'scientistadventurers' who were searching for new knowledge and new economic opportunities in largely unexplored tropical lands. ${ }^{6}$ This spirit of intrepid exploration is indicated already in the headlines of many of these accounts, including 'Across Nicaragua with Transit and Machéte' (Peary 1889), 'Exploring the Valley of the Amazon in a Hydroplane' (Stevens 1926), and 'A New World to Explore: In the Tree-Roof of the British Guiana Forest Flourishes Much Hitherto-Unknown Life' (Hingston 1932).

Typical of these accounts is the presentation of tropical forests as lands that are completely unknown. They are at the back of beyond and places that have never been trodden by the foot of a White man. The writers present heroic stories of solitary explorers who survey hitherto unknown rivers and hack their way through tangled forests, carrying heavy packs of supplies and enduring the pervasive isolation of the jungle (Holt 1933, Schurz 1936, Stevens 1926, Sultan 1932). This atmosphere of emptiness and desolation is necessary in order to justify the Western discovery and conquest of the tropical regions, presented as 'uninhabited' peripheries (Lowenthal 1997, Stepan 2001). As a symbol of conquest, many of the explorers carry the flag of their own country during their travels.

Many of these narratives also present allegories reminiscent of Robinson Crusoe of White men taming the wild forests. Gill's (1934: 139-43) account of pioneering in Ecuador offers an illustrative example: 'It seemed incredible that, out of all this disorder, we could establish a small area of civilization for ourselves by the primitive means available.' Gill's account also portrays a picture of the giant 
cinnamon tree which was the first to fall when the 'modern Crusoes' began the difficult task of carving a modern home out of the jungle. As typical of imperialist travel accounts (Pratt 1992, Spurr 1993), many of these writers use sexual images to portray their masculine conquest of the virgin forest. The term 'man' is used to refer to humans, and the female pronoun represents nature in several writings describing the traveller's eagerness to probe her [nature's] secrets and tap her [forest's] wealth.

Accounts of the hazards encountered during the expedition merely inflate the achievements of the intrepid explorers. In narrative after narrative, the explorers are beset by pounding rains and insufferable heat. They are covered with insect bites, ravaged by malarial fevers, and frightened by night-roaming jaguars. Such hardships abound in the account by Robert Peary (1889), the famous discoverer of the Pole North, of his journey through the untouched forests of Río San Juan, Nicaragua. According to Peary, the days were filled with constant obstacles, and the tropical thicket was so dense that it was impossible for even a strong, active man to penetrate through it without a machete. One had to wade in knee-deep mud and be alert for crocodiles, peccaries, and snakes. For Peary, Río San Juan was an awesome jungle, with few links to the outside world, and for this reason its exploration could not be delegated to just anyone. As such, Peary's account repeats the epoch's conventional narrative of the White man conquering the hostile tropics.

In the travel accounts of National Geographic at this time, the rainforest is most commonly presented as a 'Green Hell' and an 'enemy of mankind'. Romantic views of tropical forests as a source of nostalgia and a cradle of peacefulness are not absent either but they are much more uncommon. ${ }^{7}$ In the majority of the accounts, the rainforest is presented as a violent and disease-ridden jungle that represents an untamed savagery, including those who live there. Gloomy, wild, dismal and desolate are the typical epithets used to describe the rainforest, which is also depicted as a wall, a tunnel, or a labyrinth (Table 1). This heart of darkness is considered to be a source of fear and panic that easily engulfs the lonely travellers. Hingston (1932: 625-28) describes in his account of an expedition through British Guiana, his feelings 'of being completely shut in' by a jungle with no horizon and his 
'immeasurable relief on getting back at last into the open and enjoying the spaciousness and freedom'. Sultan (1932: 593) conjures up visions of the riotous and inhospitable vegetation of Nicaraguan rainforests 'where the footing is always insecure' and the jungle is 'so thick that you can rarely see ten feet in any direction'. According to many accounts of this time, it is easy to lose oneself in moral confusion and despair in tropical forests, where the overwhelming power of wildness strips away social conventions and invokes a more savage way of life and more sinister world-view.

Given these conceptions, a great number of the late nineteenth-century and early twentieth-century travel writings published in National Geographic consider the value of the tropical forest to arise solely from the possibility that its remarkable potential could be harnessed in the service of human progress. In these accounts, tropical rainforests appear as an obstacle to be overcome and/or as a mysterious 'El Dorado' to be discovered. This view is closely linked to the epoch's western politicaleconomic ambitions, which considered tropical forests as inexhaustible resources to be exploited and dominated by means of western scientific and technological innovations (Nugent 1994). In accordance with this conception, most of the epoch's travel writers tend to build up categorical views of tropical forest-dwellers as either 'barbarians' living in the backwoods or as 'frontier-breakers' taming the hostile jungle.

\section{INDOLENT SAVAGES VERSUS PROGRESSIVE PIONEERS}

Concerning the people living in the rainforests, the travel accounts of National Geographic during the late nineteenth and early twentieth century tend to produce strict distinctions between settlers and savages, between those who are cultivated and those who are not (Table 1). Like tropical nature itself, the rainforest Indians are considered dangerously unpredictable until controlled (Rothenberg 1994: 164-65). In the photographs of these accounts, the Indians are portrayed either as powerful hunterwarriors who glare wild-eyed at the camera or as backward savages impressed of the modern devices of the White man. Stevens (1926: 400-02) presents a picture where "the tallest of the Mayongong Indians came hardly more than shoulder-high to members of the expedition' and argues that this was 
the first time that these natives 'had any contact with the civilization'. By emphasizing the Indians' primitivism, the travel writers provide moral justifications for subjugating them.

At the same time, tropical settlers are presented as backward but hard-working pioneers who are eagerly participating in the development of modern society. Although the accounts of National Geographic of this time regret the general nonchalance of the rural people living in the neotropics, the majority of the texts laud the few settlers, who are rescuing their living spheres from a state of idleness and abandonment. These narratives praise the tropical colonists as sedulous wildernesstamers who build their homes in places where no house has ever been stood before.

From a social evolutionary perspective, the differences between Indian and settler livelihoods are interpreted as effects of uneven cultural development. In various accounts, emphasis is placed on the notion that the Indians are incapable of progress because of their lack of moral determination to conquer nature. As a consequence, the rainforest Indians are portrayed as eking out a miserable handto-mouth existence through hunting and gathering. An illustrative example of this perception is Holt's (1933: 600-01) description of how agriculture among the natives of Brazilian Amazon 'has not progressed beyond the simple stage' and how an Indian, when he travels, 'carries his entire household. The whole family go, and with a pot, a few fishhooks, bow and arrows for baggage, are prepared to live indefinitely off the country'. By depicting Indians as indolent and backward, the travel writers consider the indigenous landscapes as being in urgent need of exploitation.

Even though Indians serve as indispensable guides for many of these travellers, the native conceptions of nature rarely become an object of study (cf. Miller 1996: 12). Many of the National Geographic travel accounts of the late nineteenth and early twentieth century describe how the Indians paddle the travellers' boats, clear the forest paths, climb tree trunks, and accomplish a dozen of other tasks associated with life in the jungle. Even when they are depicted as 'born naturalists', the environmental knowledge of the Indians is described primitive, and the native inhabitants are often considered as only one step up from animals. This view is evident in the travel writers' tendency to use animal 
metaphors when referring to Indians. An expressive example of this view is Stevens' (1926: 412) disparaging comment on the Parima Indians, who stand on one leg 'like storks' when he tries to photograph them.

In many of these writings, the hunting-gathering rainforest Indians are considered doomed to give way to more progressive tropical settlers. The National Geographic writings of the late nineteenth and early twentieth century admire tropical colonists as individualistic entrepreneurs who are introducing rational ways of utilizing the tropical resources. The settlers are presented as industrious people, whose life in the 'last outposts of civilization' is extending the space of modernity toward the jungle of savagery. Holt $(1933: 587,618)$ feels for the residents of São Gabriel on the Upper Río Negro to live so far from the rest of the world that 'one wonders how the inhabitants expect to hear their patron saint' and praises the residents of Pará of their persistent efforts to get rid of the backwardness in an environment 'still beleaguered by the jungle'.

Correspondingly, the rainforest Indians are seen as incapable of any greater advance in their culture. Sultan (1932: 608) describes with disparagement how 'the huts of the Sumo Indians are simple structures, thatched with palm leaves' and 'their worldly possessions are confined to bows, arrows, blowguns, and one or two pots and pans'. As people of the woods, the Indians are supposed to express their primitive instincts; they Indians rarely speak, but either mumble or utter weird cries. Several travel writers also make sensational comments on the native inhabitants' curious customs of eating. The Indians are condemned for bolting down their food with bare fingers and eating whenever they are hungry, while, in contrast, settlers dine at certain hours and even clean their hands with a napkin after the meal.

One of the most powerful indicators of Indian primitivism in the travel accounts by National Geographic in the late nineteenth and early twentieth century is the Indians' nakedness. Many of the accounts of this time contain sensational images of the Indians' immorality: They are described to go naked like animals, without showing any shame, while moralistic comments on sexual promiscuity 
occur in several accounts of indigenous feasts. The tropical settlers are, in contrast, portrayed as people dressed in civilized clothes and the settler festivals are depicted as beautiful gatherings where gentlemen in neat shirts and trousers dance with ladies clad in showy print dresses. Peary (1889: 331) tells with delight in his account of Nicaragua how, after getting from the jungle to more civilized parts of the country, the explorer meets 'black-eyed and brown-limbed señoritas, instead of wild hogs and turkeys', and at night, 'he hears, not the scream of tigers [jaguars], but the songs of the lavandera's [laundress'] ecru daughters floating across the stream.'

Concerning the 'marvels of modernity', the late nineteenth and early twentieth century travel writings of National Geographic depict Indians as innocent primitives who are afraid of radios and who regard matches and flashlights with superstitious awe. The photographs of these accounts portray Indians examining mirrors with suspicion, thus implicitly bolstering the view that the Indians lack any selfconsciousness until contacted by modernity (cf. Hyndman 2002: 50). Stevens (1926: 408) laughs at the Maku Indians, who have difficulties in putting on their first clothes received as a gift from the White man. The account portrays a picture of the Maku chief, who finds difficulty in fastening his first shirt around his neck and "calls on his squaw for assistance, much as a civilized husband sometimes calls on his wife for help in a similar difficulty'. Sultan (1932) and Gill (1934) fret about their Indian servants, who do not understand why sheets should be tucked in at the foot of the bed or what possible use there could be for two forks at one meal. Gill (1934: 162) also makes slighting comments on the Indians, who do not comprehend the idea of typing, but are astonished "why anyone should spend so much time poking the keys merely to make rows of black marks on paper'.

In contrast to Indians' primitive life in the woods, the travel accounts of National Geographic of this time praise tropical fields and plantations as islands of opulence and civilization. As typical of imperialist travel writings, Peary (1889: 334-35) looks at the end of his journey in Nicaragua down upon the valley of Tola, where plantations and factories have replaced the wilderness. This picture gives Peary much pleasure, for it means that the 'dream of modernity' has been realized and the 'cry of commerce' has been answered. In accordance with the epoch's global political economy, many of 
these accounts express fervent optimism about the future prospects in the neotropics. Hulse (1927) and Marden (1934) are convinced of the success of converting tropical forests into coffee plantations and cattle estates in Central America, while de Pinedo (1926) has ambitious visions of the introduction of steamboats and sawmills in Amazonia. A similar vision of the western exploitation of the neotropics continues in the majority of the magazine's travel writings up till the 1970s, when the representations of neotropical forests and neotropical forest-dwellers portrayed in the magazine start to revert in articulation with the ghanges in global environmental policies and public opinions concerning the rainforests.

\section{PRESERVING THE 'VERDANT EDEN'}

Whereas the late nineteenth century and early twentieth century travel writings of National Geographic on the neotropics were heroic accounts by 'modern Crusoes' who struggled to conquer the hostile Inferno of Nature, most of the magazine's recent travel writings present the rainforest as a fragile sanctuary that demands assiduous care. It is lauded as an earthly Garden of Eden, where eternal greenery and untamed luxuriance reign. This evergreen realm is seen as a refuge from the ills of civilization and as a source of tranquillity of the human spirit (McIntyre 1988, Webster 1998).

This reversal from the portrayals of the Green Hell to the images of the Threatened Paradise has close links to the international concern for tropical deforestation and forest degradation that came into prominence in the early 1970s (Nugent 1994, Slater 2002: 9-16). Under the banner of a new environmental awareness and new environmental politics, the rainforests have since then been portrayed as endangered global resources, whose destruction presents worldwide risks and whose rescue from obliteration requires worldwide efforts. They are a biome of incredible richness and a source of intellectual insights awaiting wide-eyed scientists; they are the Earth's green belt, the world's largest reservoir of genetic traits and an irretrievable memory bank that has evolved over billions of years (Melham 1990, Morell 1999, White 1983). 
As a consequence, the tropical rainforests are losing their earlier hostile image and becoming places of dispassionate protection. Many of today's writings on the neotropics published in National Geographic are written by persons who have participated in scientific expeditions to learn about the natural wonders of the rainforests and to understand the complexity of tropical ecosystems. These accounts contain detailed descriptions of scientists who devote themselves to studying the tropical hotspots of biodiversity and training the native peoples to preserve their environmental and cultural heritages (Garrett 1989, O’Neill 1993, Kamper 2000, Morell 1999).

The second type of contemporary travel accounts published in National Geographic are those narratives which yearn for originality and adventure. Whereas the earlier accounts portrayed images of explorers who went to the tropics to discover 'untouched' territories, modern accounts tell about travellers who go to the tropics to (re)discover their 'authentic' self (Blanton 1997: 1-29, Short 1991: 60-61). These writers emphasize the spiritual regeneration and the mental renewal experienced during their tropical journeys. Typical of these individual odysseys is the presentation of rainforests as places of recreation instead of work, and spaces of spectacular feelings instead of sober observation. To distinguish themselves from 'ordinary' tourists, the travellers trek into the most intact forests and visit the most hidden peoples to know the rainforests and their inhabitants intimately (Risse 1998, Steve 1999). Schreider and Schreider (1970), and Chmielinski (1987) describe their participation in the race to be the first team to navigate the Amazon from the source to sea and to see with their own eyes every foot of this unique waterway.

The third group of contemporary travel accounts in National Geographic are those narratives in which the writer devotes himself/herself to efforts to understand the native culture and to record the Indians' traditional way of life. These writers focus their narrative on describing their extraordinary experiences while living among the 'last Indians'. Their accounts are framed in the language of cultural relativism, and they eagerly position themselves as 'specialists in other cultures'. Webster's (1998) account of his visit among the Yanomami offers an illustrative example. Ignoring the rich anthropological literature on the Yanomami, Webster (1998: 8-13) argues that the Yanomami territory 
is so little explored that even few anthropologists 'are allowed into these forests'. He then describes how the Yanomami greeted him with hoots and screams and how their headman repeatedly slapped him on the chest as a sign of welcome. In many of these accounts, native people are described as 'my' Indians, whose acceptance the traveller wins to the point that he/she is treated like kin. The passion of 'going native' makes the traveller eager to adopt the Indian way of life, including having his/her body painted with ritual colours and participating in the Indians' secret ceremonies.

Characteristic of the contemporary travel writings published in National Geographic is the writers' narcissistic tendency to focus on their own feelings and their own reactions to the tropics. Compared to earlier writings, current travel accounts contain more pictures of the travellers themselves. The traveller's unique appreciation of the tropical landscape becomes the main focus of inquiry in repeated descriptions of hiking in a 'pristine' forest that stretches to the horizon, devoid of any sign of human presence. According to Schreider and Schreider (1970: 109), 'cruising for hours past walls of unbroken forest, we sometimes seemed to be the only boat on the river [Amazon], the only people'. Kamper (2000) describes how the first view of the Madidi National Park in Bolivia compensated all the difficulties of the journey: 'Breathtaking landscapes, abundant birdlife, utter wildness as far as the eye could travel'.

At the same time, today's travel writings on the neotropics convert the earlier images of chaotic jungles into pictures of marvellously complex rainforests. This perception becomes clear already in the titles of recent National Geographic accounts, among them 'Nature's Dwindling Treasures: Rain Forests' (White 1983) and 'Wilderness Headcount' (Morell 1999). The image of rainforest as a threatened Garden of Eden is reinforced by verbal and visual references to paradisal icons. The rainforest is depicted as breathtaking, spectacular, fabulous, and majestic (Table 1). ${ }^{8}$ It is a place that 'feels like paradise', where 'scarlet macaws fly overhead, their wings pounding against the jungle twilight's electric blue sky' (Webster 1998: 11). It is also a green cathedral, a living pharmacy, and an immense library whose unbridled burning makes the burning of the ancient library of Alexandria insignificant by comparison (McIntyre 1998: 817, Melham 1990: 118-19, White 1983: 24). 
The current situation, in which the tropical rainforests are "rapidly being clear-cut, stripmined...bulldozed, and burned' (Melham 1990: 113), leads the contemporary National Geographic travel writings to underscore the urgent need for international intervention on behalf of tropical conservation. Many of these accounts paint ominous pictures of the worldwide disaster that will result from the conversion of this lush greenery into a rusty red desert (Ellis 1988, McIntyre 1972, McIntyre 1988, White 1983). ${ }^{9}$ In contrast to earlier accounts which championed the uncontrolled exploitation of tropical resources, current narratives of National Geographic draw ugly pictures of tropical forest frontiers whose natural resources have been brutally degraded. To substantiate this view, the rainforests are described as razed, raped or denuded (Garrett 1989: 439, Mcintyre 1977: 708, Kamper 2000: 16, White 1983: 31). Through oversimplified interpretations of ongoing environmental policies and programmes of forest management in the neotropics, any use of rainforest is easily condemned as an abuse.

\section{FOREST-FRIENDLY VERSUS FOREST-UNFRIENDLY CULTURES}

Parallel to the changing views of the rainforests, the dominant images of tropical forest-dwellers produced in the travel accounts of National Geographic have changed considerably in recent decades. Indians, whose impact on nature was dismissed as derisory in earlier accounts, are now depicted as guardians of the forest, blessed with inherent environmental wisdom. They stand in sharp contrast to the small-scale settlers and non-indigenous rural poor, whose relationship to nature is considered to be based on short-term forest encroachment and who are easily portrayed as unruly forest ravagers, with little awareness of the need to protect nature (Table 1).

This new rhetoric has much to do with the growing worldwide concern about the survival of the tropical forests, which has promoted the environmentally-founded rediscovery of the rainforest Indians as providers of a human face for the global attempts at rainforest protection (Brysk 2000, Conklin and Graham 1995, Oakdale 2004). Characteristic of this discourse is the inclusion of native 
peoples as a part of this magnificent nature. The Indians are equated with the tropical flora and fauna as part of the overall spectacle of a divine fragility that needs protection (Slater 2000). This view becomes clear in various accounts of National Geographic on the Indians, who blend into the forest background so completely, that they seem to be part of the landscape. In many of the contemporary travel narratives, the Indians either stand silently in the forest like statues - which make it difficult to visualize one separated from the other - or when speaking for themselves, they present themselves as faithful stewards of nature (Devillers 1983, van Dyk 1995, Webster 1998).

At the same time, current National Geographic travel writings project tropical settlers as nomads who pour into the tropical forest frontiers like pigeons. While the Indians are described as profoundly territorialized peoples in metaphors that refer to roots and soils, the settlers are depicted as culturally uprooted populations with liquid metaphors of movement (cf. Malkki 1992, Nygren 2004). A great many of recent National Geographic accounts tell about waves of colonists and floods of migrants that stream into the forests to hack out homesteads. The settlers are also described as hordes of pioneers and swarms of land-hungry colonists, who scatter like lemmings into the jungle. According to Ellis (1998: 788): 'They [settlers] came on foot and by bicycle. They came clinging to one another as they rode on top of cargo in trucks that undertook the axle-braking journey along the access road. They came in the rain, and they came during the dry season...And when they came to claim the land, they brought with them all the social ills of a frontier boom.'

This view of nature-friendly versus nature-unfriendly forest-dwellers has brought the rainforest Indians into the limelight of global media's admiration. According to recent travel writings of National Geographic, the Indians are free denizens of the jungle who live in the rhythm of the forest and who feel a sense of oneness with nature. The small-scale colonists seldom receive a similar amount of attention, simply because they do not represent such an exotic way of life, nor can they claim the same status as champions of nature (Nugent 1994). When presented in current writings, the settlers are rather portrayed as rootless penetrators whose commitment to the forest is transitory and who mindlessly destroy nature's precious gifts. The settlers' livelihood strategies are also described as 
a 'drama of man against the jungle' (Schreider and Schreider 1970: 117) or a 'veritable war between man and nature' (White 1983: 38). In National Geographic special number on Tropical Forests in 1988, McIntyre's article on the Urueu-Wau-Wau Indians is entitled 'The Last Days of Eden', while the article by Ellis on Amazonian colonists is entitled 'Brazil's Imperiled Rain Forest: Rondônia's Settlers Invade'. Similar metaphors are produced in the magazine year after year. The Indians are presented as innocent children in a pristine forest, and noble savages on the land that time forgot, while small-scale settlers are portrayed as villains battling against untouched nature and as nomads with a manic zest for migration.

Characteristic of these representations are the portrayals of the breathtakingly beautiful rainforests, with giant trees and cascading rivers. The brilliantly-plumaged macaws, blossoming helicons, and jewellike orchids form an integral part of this enchanted realm, in which sensitive humans harmoniously participate. The Indians are portrayed as self-sufficient in the wildness and completely reliant on what nature provides (Webster 1998, White 1983). They speak a language that resembles lullabies, and, even when working, they are smiling. This view of Indians living in the forest free from the chains of civilization is illustrative, for example, in Melham's (1990: 154) description of his trip among the Yanomami: 'Just outside [the Yanomami lodge] stood eight or ten visiting Mucajai Indian women, nude save for their tangas (string girdles), and all smiled as they painted stripes, zigzags, and delicate stylized flowers on each other's skin. They were so happy, so full of childlike delight and innocence in the bright sunlight.'

According to contemporary travel writings, this transcendent beauty of pristine forests is on the verge of being swallowed up by the massive flow of colonists, who are portrayed as harmful elements in the global drive to protect tropical nature. The images of the small-scale settlers produced in recent travel accounts of National Geographic include portrayals of intractable invaders who see the forest as an adversary and who are led to the jungle by an ardent spirit of pioneering. The settlers' parcels in the burned-down jungles, littered with skeletons of trees and smouldering stumps, are portrayed as 'a cigarette burn in a vast green carpet' (Garret 1989: 434). They are also described as 'malarial acres' 
which 'lie blackened and scarred like a battlefield in war' (Ellis 1998: 782).

In accordance with this view, the settlers' life on the forest frontier is portrayed as gloomy and unattractive, where makeshift houses proliferate across the landscape, and insects are the only wildlife around cleared areas' (Ellis 1988: 788). The children's stomachs are bloated with parasites and their bodies are covered with fleas (McIntyre 1977, van Dyk 1995). The settler populations, lacking the 'somebody-ness' of the Indians, are seen as vacant and undefined: They represent the menacing other. As if to substantiate this, male settlers are often shown girded with a machete or a rifle slung over their shoulders.

At the same time, the settlers' living spheres are depicted as political trouble zones and threats to the established social order. These depictions assume that poverty on the tropical forest frontiers is mainly a psychological process stemming from the settlers' deficient identity. In an account of his travels on the Amazonian frontier, McIntyre (1977) describes the frontier as an undercurrent of lawlessness where machismo reigns and where issues are usually decided at the point of a gun. According to Ellis (1988: 783-88), the Amazonian frontier drama is turning 'to full throttle' where 'people staring and seldom smiling' fight, guzzle and hung around in night music of debauchery. Many of the writings emphasize the similarity of tropical frontiers to the North American Wild West a century ago.

Analogous to these highly charged images is the presentation of rainforest Indians as colourful ritual performers whose culture is a spectacle, rich in myth and mystery. In contemporary National Geographic travel accounts, the native people are often illustrated in ritual decorations even when working. There are also descriptions of Indians with their 'pre-Columbian' dugout canoes, the canoe thus becoming an icon of the Indians' timeless life-style. An advisory example of this kind of iconization is van Dyk's (1995: 27) description of how 'six Indians paddling past just a few feet away, arrow-shaped paddles dipping silently in the river. It seemed an ancient image, almost a dream.' Likewise, there are portrayals of an Indian hunter who skilfully bends his bow and takes careful aim, his naked, bronze body looking like a statue silhouetted against the sky. Motionless, he awaits the 
proper moment until his arrow impales the prey. This dynamic unity, formed by the Indian body and the tropical landscape, is depicted as a symbol of a fragile beauty of the indigenous world, associated with ancient roots and with timeless attachment to pristine nature (Devillers 1983: 66, Kamper 2000: 21, Schreider and Schreider 1970: 72, von Puttkamer 1971: 436, 440).

The settlers' life is, on the contrary, sensationalized by accounts of poverty and brutality. While Indians are presented as skilful archers, the settlers are portrayed as drudging colonists, clearing the land more as a 'burden rather than a skill' (Lutz and Collins 1992: 146). The Indian women are illustrated as smiling mothers dandling their babies in hammocks, while non-indigenous females are portrayed as apathetic women who are heavily pregnant or burdened with wailing infants (Devillers 1983: 77, McIntyre 1977: 708). While Indian women are depicted as sexually aesthetic and alluring others, with their naked bronze bodies, non-indigenous women are portrayed as indiscreet and excessive in their sexuality. Von Puttkamer (1971: 440) tells about his encounter with three Cinta Larga women: "who wore necklaces of dyed nutshells and almost nothing else. Though demure, they were unabashed and headed directly for our kitchen.' Impressed by the Indians' poise, von Puttkamer named them the 'Three Graces'. In contrast, Mcintyre (1977: 691) describes his unpleasant experience on a Brazilian frontier, where thirty men 'showed up on Saturday night to share dollar-a-bottle Coke and warm beer by candlelight with forlorn-faced women'.

Such dichotomized views produced of the indigenous and settler life-styles also suggest categorical differences in personalities. The Indians are said to live satisfied with their lot, free from materialism and repressive societal conventions. The settlers are, on the contrary, portrayed as corrupt schemers who penetrate farther into the jungle in their eagerness to exploit whatever resources. In the photographs, the Indians are typically presented in profile against a greenery that gives no evidence of social context, thus showing more interest in the Indians' place in nature than in their links to the larger society (Ramos 1994). The settlers are, instead, illustrated standing in a crowd and staring directly at the lens, all of which carries a message of their anarchic way of life and their threatening potential for violence. 
Analogous to these images, the journeys to Indian territories are depicted as voyages of discovery, creating the impression that visiting these people is like moving back through the millennia. The travellers launch forth from the modern city to a remote jungle, where the Indians have survived with minimal changes in their 'Pre-Columbian cultures' (Garrett 1989, Webster 1998, von Puttkamer 1979). In this pre-modern realm, modern techniques have little validity and western sense of superiority easily looses its power. The Indians laugh at innocent travellers who bring insecticides into rainforest and who do not know how to survive in the jungle. Schreider and Schreider (1970: 62-63) describe how a Campa Indian 'glided through the jungle like a wraith... moving silently that the symphonic trill of unseen birds and insects hardly changed its pitch'. As the Schreiders clumped after him, 'feet squishing in the damp sponge of rotting vegetation, it seemed as though the conductor had dropped his baton'. Correspondingly von Puttkamer (1971: 435) tells about how 'Cinta Larga boys allowed the travellers' to accompany them on hunting trips, but expected them to carry the game they killed. When they came to streams deep enough to harbour electric eels, the Indians silently climbed upon the travellers' backs.

At the same time, the settlers' living spheres are presented as an ugly monotony of the curses of modernization or as a helter-skelter of pre-modern backwardness and post-modern chaos. Schreider and Schreider (1970: 109) tell about Amazonian frontier towns, where their journey 'began to follow a script that never varied: The same greying wood shacks, the same bleached thatch roofs and dusty red streets, the same stocks of cane alcohol, cigarettes, and canned beef in the same bare-shelved shops'. Sartore, the photographer who accompanies Kamper (2000: 28) in his journey to Bolivia, feels the same in the frontier town of Pelechuco: 'Poverty abounds. Everything is worn out or broken. The kids...swim in raw sewage'. Van Dyk (1995) and Webster (1998) both wonder at the architectural disharmony of Amazonian frontier cities, where cardboard shacks and skyscrapers, dugout canoes and high-tech containerships, mix abruptly with each other. In contrast to earlier travel accounts, which presented the modernization of the tropics as a panacea, current travel writings evoke nostalgic sentiments toward the vanishing pre-modern world, unspoiled by ills of globalization. 


\section{CONCLUSION: TRAVEL WRITINGS AND TROPICAL TROPES}

This essay has analyzed the representations of tropical forests and tropical forest-dwellers in travel accounts of National Geographic on tropical America. Instead of rehearsing the conventional dichotomy between 'we' and the 'other', this essay has shown that the travel writings of National Geographic produce representations of neotropical forest-dwellers that rest on essentialist categorizations of 'good' and 'evil' others. In the late nineteenth and early twentieth century accounts, rainforests are typically presented as 'Green Hells' and rainforest Indians as primitive savages, while the tropical settlers are praised as virtuous pioneers who are exploiting the tropical jungles. Since the growing global concern of tropical deforestation and forest degradation in the early 1970s, the accounts of National Geographic have instead depicted rainforest Indians as faithful guardians of marvellous forests, while tropical settlers are seen as mindless destroyers of tropical biodiversity. These historically changing, but equally essentialist images are based on repeated contrasts between the 'virtuous' and the 'vicious'.

The importance of the role of travel writings in formulating popular conceptions of tropical forests and tropical peoples can hardly be overestimated. With the global spread of tourism, travel narratives

- like travel itself - have been made available to a large audience, and the genre of travel writing has become one of the most popular and widely read forms of literature today (Holland and Huggan 1998: 1-2). This essay has intended to show the crucial role that travel accounts in such a well-established brand as National Geographic have played in how the neotropics and the neotropical peoples have been envisioned over time. While referring to actual people and places, the National Geographic travel accounts are interspersed with fictitious stories, thus producing a series of powerfully distorting and highly selective images of neotropical forests and neotropical forest-dwellers. In spite of these fictitious elements, the writers in National Geographic present their narratives as authentic transcriptions of reality with little recognition of the inequality of the encounter and little analysis of how the encounterer's life is related to that of those whom he/she encounters. ${ }^{10}$ 
Most of the travel accounts in National Geographic operate within a pre-established semantic field, repeating the same phrases and same tropes over and over again, while excluding the elements that do not accord with the conventional conceptions. Although the prevailing images portrayed in the accounts have changed over time, the same categorizations as friendly versus unfriendly and pure versus impure, crop up repeatedly. The majority of the accounts present the Indians' and the settlers' conceptions of their environment as monolithic, with little recognition of the existing intracultural diversity in the ways human beings experience nature. At the same time, the differences between the indigenous and the settler landscapes are categorized as purely cognitive, with little recognition of the different conditions that these people encounter in meeting the daily requirements of livelihoods. There is also little recognition of these people's differentiated positions in relation to wider society, governmental policies, and global environmental agendas and advocacy networks.

While the late-nineteenth and early-twentieth century travel writings of National Geographic demonstrate an imperialist desire to control tropical nature-society relationships by constructing essentialist images of culturally primitive Indians and culturally progressive pioneers, the present-day writings' images of rainforests as a threatened Eden and a realm of nature that demands global protection rest on a similar kind of desire for control. The overall concern for what is natural overshadows the tropical forests as historical, political, and cultural spaces (Nugent 1994, Slater 2000: 76-77). The contemporary travel writings of National Geographic on tropical landscapes and tropical peoples are especially thin in history, positing tropical forest-dwellers as ahistorical beings with little knowledge of the world around them. By considering cultural difference as a result of distance and isolation, they show little interest in analyzing the links between the representations and the wider issues of control and power (Kirsch 1997). The argument made in many writings that the protection of nature is an inherent aspect of native life portrays the Indians in terms of Western images of 'born naturalists'. This image does not necessarily coincide with the Indians' own visions, which are based on increasing self-determination and control over their own resources (Conklin and Graham 1995, Oakdale 2004, Ramos 1998). 
In the same way, cultural mentality is used as an overall explanation for non-indigenous settlers' environmental behaviour, with little interest in the deeper structural roots of resource destruction on tropical forest frontiers, including unequal control over resources and settlers' vulnerable position in relation to global economy. Little insight is also given into the forest frontiers as places of social injustice and political marginalization. This reification of people's relationship with nature fails to recognize the diversity of lived environmental relations and the complexity of the power struggles that mediate the ebb and flow of competing environmental images and environmental policies concerning tropical forests and tropical forest peoples (Graham 2002, Nygren 2000, Raffles 1999). It also ignores the fact that, in reality, the majority of the indigenous and non-indigenous neotropical forest-dwellers have for centuries been the most marginalized members of their national societies. In the earlier travel accounts of National Geographic, the social exclusion of Indians is wrapped in the pejorative remarks of their cultural primitiveness, while today's narratives package it with picturesque images of Indians living in the peace of mystery. Correspondingly, the social marginalization of the small-scale colonists is shrouded in their frontier-breaker mentality in the earlier accounts, while contemporary travel narratives package the settlers' subordination with references to their cultural uprootedness.

All this shows how the representations of tropical forests and tropical forest-dwellers produced in travel writings of National Geographic create powerful moral narratives, with limited concern for what these people might be on their own account. Despite the writers' intentions to approach tropical peoples with open minds, essentialist distinctions prevail. In this context, there is a need for renewed approaches that would permit more diversified views and more plural accounts to emerge. Such perspectives could reflect more complex views of tropical peoples and reveal the multifaceted patterns of exchange and interaction that take places when different realities mingle together. They could also show the artificiality of making categorical distinctions between what is 'authentic' and what is 'spurious'. In today's world of globalization and hybridization, one can no longer predict who will put on the loincloth and lift up the blowgun and who will put on the Gore-tex and pick up the mobile telephone. 


\section{NOTES}

${ }^{1}$ See www.nationalgeographic.com (visited on 10 June 2005).

${ }^{2}$ I am well aware of the problems involved in terms 'Western' and 'non-Western', or 'First World' and the 'Third World'. My use of these terms includes a critical notion that none of these categories is a monolith nor can they be considered to exist in sharp distinction with each other.

${ }^{3}$ A similar dichotomy is found in much academic and advocacy literature, which distinguishes ecologically benevolent indigenous peoples from settlers as enemies of sustainability. For criticism of such dichotomies, see Li (2000), Nugent (1997), Nygren (1998, 1999) and Slater (2000).

${ }^{4}$ Non-Numerical Unstructured Data Indexing Searching \& Theorizing Qualitative Data Analysis Program, version 6.0, 2002. QSR International, Melbourne, Australia.

${ }^{5}$ In this respect, see also the study by Conklin (2001) on the European colonizers' attitudes toward Wari Indian cannibalism which offers an inspiring analysis how the discourses of horror and disgust became interwoven with the discourses of humanism and cultural relativism in the colonizers' accounts.

${ }^{6}$ Although some of these 'scientist-travellers' had no direct links to Western political and commercial ambitions in the tropics, their intensive investigations unquestionably furthered Western economic exploitation of the tropics (Slater 2000: 12, Stepan 2001: 31).

${ }^{7}$ For more on the historical ambiguities in the images of tropical forests, see Arnold (1996), Putz and Holbrook (1988), Raffles (2002), Slater (2002) and Stepan (2001).

${ }^{8}$ Of course, there are also descriptions of rainforests as gloomy channels and tangled jungles, but not in the same frequency as in earlier writings.

${ }^{9}$ This does not, of course, mean that there are no problems of deforestation or environmental degradation on tropical forest frontiers.

${ }^{10}$ This is not to say that all the presentations of tropical forest-dwellers in National Geographic are categorically reified. Several writers note the discrepancy of images in tropical resource conflicts, by stating that the conflicts are complex and difficult to understand. White (1983) also recognizes that the problem of tropical deforestation reaches far beyond settler culture into economic and socio-political assets in a situation where small-scale colonists suffer from a lack of assistance and intimidating bureaucracy. 